\title{
Lecznicze zastosowania limonenu
}

\section{Therapeutic applications of limonene}

\author{
Monika Retajczyk, Agnieszka Wróblewska ${ }^{\varpi}$ \\ 'Zachodniopomorski Uniwersytet Technologiczny w Szczecinie, Instytut Technologii Chemicznej Organicznej, ul. Pułaskiego 10, 70-322 Szczecin \\ West Pomeranian University of Technology Szczecin, Institute of Organic Chemical Technology \\ ${ }^{2}$ Zachodniopomorski Uniwersytet Technologiczny w Szczecinie, Zakład Syntezy Organicznej i Technologii Leków, al. Piastów 42, 71-065 Szczecin \\ West Pomeranian University of Technology Szczecin, Department of Organic Synthesis and Drug Technology \\ $\triangle$ agnieszka.wroblewska@zut.edu.pl
}

\begin{abstract}
Introduction: Limonene is a monoterpene compound which in nature occurs in the form of two isomers, $\mathrm{R}$ and $\mathrm{S}$. From these two isomers, particular attention is now given to R-(+)-limonene, mainly because it can easily be obtained from cheap and renewable raw materials (waste orange peel) and the numerous and varied uses of this compound in medicine, cosmetics and perfumery.

Materials and methods: This review article describes the use of limonene. Particular emphasis was put on describing the uses of this compound in medicine. Literature data show that limonene in many cases has a therapeutic effect. The article also draws attention to the safety of limonene applications, proven in the reported experiments on humans and animals. The study also describes the metabolism of limonene in the human body, as well as studies on the allergenic effects of limonene's oxidation products, both $\mathrm{S}$ and $\mathrm{R}$ isomers. These studies highlight the importance of limonene peroxides, which have the strongest allergenic properties. In addition, studies on the antibacterial, anti-inflammatory and antifungal effects of limonene are presented. This article
\end{abstract}

also describes the effect of Ras protein in the body of a healthy person, shows its association with carcinogenesis, and presents studies in which limonene acts as an anti-cancer agent, e.g. by inhibiting the prenylation of this protein. This work provides information on limonene-induced phases I and II of carcinogen metabolism catalysed by cytochrome P450. Studies show that limonene is an active compound both in therapy and in cancer prevention. Various uses of limonene have been studied so far, including the treatment of heartburn and gallstones, and also as a component of a topical gel for rheumatoid arthritis.

Results and conclusions: Limonene is a compound that can easily be extracted from waste, which is an obvious advantage in its application. Disadvantages in the use of limonene are the allergenic properties of its oxidation products. This review shows the numerous applications of limonene in medicine and indicates reasons for further research on this compound. One of the most important directions could be research on preventing the oxidation processes of this compound.

Keywords: limonene; monoterpenes; gallstones; antitumour activity; antibacterial properties; allergies.

\begin{abstract}
ABSTRAKT
Wstęp: Limonen jest monoterpenem, który w przyrodzie występuje w formie dwóch izomerów R i S. Z tych dwóch izomerów szczególną uwagę zwraca się obecnie na R-(+)-limonen, głównie ze względu na łatwość jego pozyskania z tanich i odnawialnych surowców naturalnych (odpadowe skórki pomarańczy) oraz bardzo liczne i różnorodne zastosowania, m.in. w medycynie, kosmetyce i przemyśle perfumeryjnym.

Materiały i metody: Artykuł jest pracą przeglądową, w której omówiono zastosowania limonenu, przy czym duży nacisk został położony na opisanie zastosowań tego związku w medycynie. Z danych literaturowych wynika, że limonen w wielu przypadkach wykazuje działanie lecznicze. W artykule zwrócono także uwagę na bezpieczeństwo stosowania limonenu, czego dowodem są opisywane w literaturze wyniki doświadczeń przeprowadzonych na ludziach i zwierzętach. Opisano również metabolizm limonenu w organizmie człowieka, a także badania nad alergizującym wpływem produktów utlenienia limonenu, zarówno izomeru S, jak i R. W badaniach podkreśla się znaczenie nadtlenków limonenu, które mają najsilniejsze właściwości alergizujące. Omówiono również badania, w których limonen wykazuje działanie antybakteryjnie, przeciwzapalnie i przeciwgrzybicze. W artykule
\end{abstract}

opisano także działanie białka Ras w organizmie zdrowego człowieka, ukazano jego związek z kancerogenezą oraz przedstawiono badania, w których limonen działa przeciwnowotworowo, m.in. poprzez hamowanie prenylacji tego białka. Praca dostarcza informacji o inicjacji przez limonen I i II fazy metabolizmu kancerogenów katalizowanego przez cytochrom P450. Wykazano, że limonen jest aktywnym związkiem zarówno w leczeniu, jak i profilaktyce przeciwnowotworowej. Do tej pory zbadano różne zastosowania limonenu, który był stosowany w leczeniu zgagi, kamicy dróg żółciowych, a także jako składnik żelu stosowanego miejscowo w reumatoidalnym zapaleniu stawów. Wyniki i wnioski: Limonen jest związkiem, który łatwo można pozyskać z odpadów, co jest niewątpliwą jego zaletą. Niedogodności w stosowaniu limonenu wiążą się z właściwościami alergizującymi produktów jego utleniania. W pracy ukazano liczne zastosowania limonenu w medycynie, będące powodem, dla którego warto skupić uwagę na dalszych badaniach nad tym związkiem. Jednym z bardzo ważnych kierunków mogłyby być badania nad zapobieganiem procesom utleniania tego związku. Słowa kluczowe: limonen; monoterpeny; kamica żółciowa; aktywność przeciwnowotworowa; właściwości przeciwbakteryjne; alergie. 


\section{WSTĘP}

Limonen jest głównym składnikiem olejku ze skórek pomarańczy, który można otrzymywać na wiele sposobów, np. w procesie destylacji z parą wodną, destylacji wodnej, ekstrakcji cieczą nadkrytyczną czy z użyciem mikrofal. W przemyśle najczęściej stosuje się tłoczenie. Proces ten zachodzi bez konieczności zwiększania temperatury i dlatego jest nazywamy tłoczeniem „na zimno”. Głównym składnikiem olejku pozyskanego w procesie tłoczenia jest limonen (ponad 90\%). Poza limonenem w skład olejku eterycznego wchodzi ok. 90 związków, z których w większych ilościach występują: mircen, sabinen, $\gamma$-terpinen i $\alpha$-pinen. Dzięki przyjemnemu zapachowi limonen jest często stosowany jako dodatek do żywności, perfum, kremów, mydeł i produktów czyszczących wykorzystywanych w gospodarstwie domowym. Ponadto limonen wykazuje właściwości przeciwgrzybicze, bakteriostatyczne oraz bakteriobójcze, dzięki czemu ma potencjał do zastosowania jako substancja konserwująca $[1,2]$.

Limonen jest monoterpenem występującym w formie dwóch izomerów (R i S), które są względem siebie enancjomerami (ryc. 1). Związek ten był używany w leczeniu takich dolegliwości jak zgaga oraz stosowany w rozpuszczaniu kamieni żółciowych. Wadą stosowania limonenu są właściwości alergizujące produktów jego utleniania.

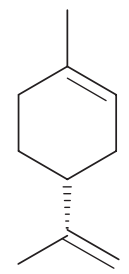

R-limonen

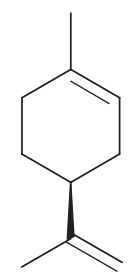

S-limonen
RYCINA 1. Struktury izomerów limonenu

Celem pracy było ukazanie szerokich zastosowań limonenu w leczeniu. Przy czym konieczne są dalsze badania, które pozwoliłyby na poznanie potencjału tej substancji. Przyglądając się właściwościom limonenu ukazywanym w licznych badaniach, można dostrzec, że związek ten poprawia perystaltykę, co może zostać wykorzystane chociażby w leczeniu zaparć.

\section{MATERIA $Ł Y$, METODY I WYNIKI}

\section{Metabolizm limonenu w organizmie człowieka}

Dzienne spożycie limonenu przez człowieka zależy od rodzaju spożywanych produktów. Limonen jest naturalnym składnikiem np. owoców. Związek ten stanowi również dodatek do wielu produktów żywnościowych. Powoduje to, że przeciętna osoba spożywa aż 0,27 mg limonenu na kg m.c. dziennie. Przy czym dla osoby o masie 60 kg ilość spożytego limonenu w ciągu jednego dnia wynosi 16,2 mg. R-limonen podawany doustnie jest bardzo szybko i prawie całkowicie wchłaniany w przewodzie pokarmowym. Po spożyciu 1,4 g R-limonenu po 48 godz. zostaje wydalone z moczem 52-86\% przyjętej dawki. Po spożyciu R-limonen i jego metabolity są obecne w wyższym stężeniu w tkankach, które zbudowane są z komórek tłuszczowych, a także w gruczołach mlecznych. Mogą być również obecne w surowicy krwi, wątrobie, nerkach i w innych tkankach. Czas połowicznego rozpadu limonenu w organizmie człowieka wynosi 12-24 godz. Co istotne, nie stwierdza się akumulacji metabolitów R-limonenu po powtarzającym się dawkowaniu przez 21 dni. R-limonen metabolizuje w organizmie człowieka głównie do kwasu perillylowego, kwasu dihydroperillylowego i limonen-1,2-diolu (ryc. 2) [1].
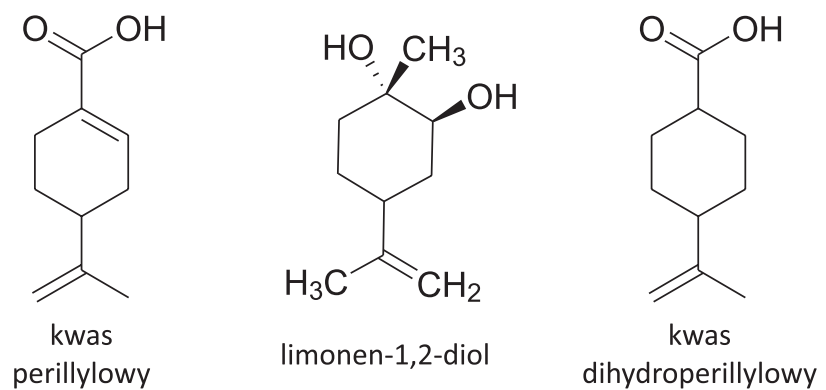

RYCINA 2. Główne metabolity limonenu w organizmie człowieka

\section{Toksyczność limonenu w badaniach na zwierzętach}

W badaniach nad myszami wykazano, że $\mathrm{LD}_{50}$, czyli dawka R-limonenu powodująca zgon połowy osobników w ciągu $30 \mathrm{dni}$ po podaniu, wynosi 5,6 g/kg m.c. dla osobników męskich i 6,6 g/kg m.c. dla osobników żeńskich. Wykazano, że podanie $10 \mathrm{~mL}$ R-limonenu do dwunastnicy szczurów nie powoduje nieprawidłowości histopatologicznych. Zbadano również wpływ R-limonenu na pęcherzyk żółciowy świni. Do pęcherzyka żółciowego wprowadzano $20 \mathrm{~mL}$ R-limonenu raz dziennie przez 2 dni. Po 24 godz. od wprowadzenia ostatniej dawki R-limonenu nie stwierdzono nieprawidłowości histopatologicznych ani w błonie śluzowej pęcherzyka żółciowego, ani w przewodach żółciowych i dwunastnicy, które były bezpośrednio narażone na działanie R-limonenu. W innych badaniach R-limonen był również podawany psu przez cholecystostomię w czasie $7 \mathrm{dni}$ i w dawkach po $10 \mathrm{~mL}$. W dniu po podaniu ostatniej dawki nie wykazano większych anomalii z wyjątkiem niewielkiego nacieku komórek zapalnych oraz zwłóknienia w brodawce Vatera [1].

\section{Bezpieczeństwo stosowania limonenu w badaniach na ludziach}

W celu zbadania bezpieczeństwa stosowania limonenu u ludzi podano 3 zdrowym osobom jednorazową dawkę $20 \mathrm{~g}$ limonenu. Badani stwierdzili wzrost częstotliwości wypróżnień i uczucie parcia na stolec. Badanie krwi nie wykazało żadnych anomalii świadczących o zaburzeniach pracy wątroby, trzustki i nerek. R-limonen okazał się również bezpieczny, gdy był przyjmowany w dawce $100 \mathrm{mg} / \mathrm{kg}$ m.c., co odpowiada ok. $7 \mathrm{~g}$ dla przeciętnego dorosłego. Zarejestrowano jedynie łagodne objawy, takie jak odbijanie się w czasie 4 godz. od spożycia dawki limonenu, 
lekkie uczucie sytości przez 10 godz. od spożycia oraz senność. Maksymalną tolerowaną dawką przyjmowaną doustnie było $15 \mathrm{~g}$ na dzień. Większe dawki powodowały nudności i wymioty. Wniosek z przeprowadzonych badań jest taki, że R-limonen miał niską toksyczność zarówno po pojedynczym przyjmowaniu przez ludzi, jak i wielokrotnym nawet przez rok [3].

Limonen jest jednym z najczęściej wykorzystywanych terpenów zapachowych w perfumach. Związek ten łatwo ulega utlenieniu na powietrzu, a utlenione produkty wywołują alergie (ryc. 3). Badania nad alergizującymi właściwościami produktów utlenienia limonenu prowadzono w 6 europejskich klinikach dermatologicznych, gdzie przetestowano wpływ mieszaniny izomerów S i R utlenionych produktów limonenu poprzez skórną aplikację u 2411 pacjentów. Spośród przebadanych osób u 2,6\% pacjentów z zapaleniem skóry zaobserwowano reakcję alergiczną na jeden lub oba produkty utlenienia izomerów limonenu. Przetestowano również wpływ produktów utlenienia izomeru S i izomeru R na 1812 pacjentach, którym podawano te izomery osobno. U 49 osób zaobserwowano reakcję alergiczną, spośród których w 57\% przypadków zaobserwowano uczulenie zarówno na utlenioną formę izomeru $\mathrm{S}$ i R. Reakcję tylko na utlenione formy R-limonenu wykazało $27 \%$ osób, u których wystąpiła reakcja alergiczna, a 16\% tylko na produkty utlenienia S-limonenu. U 2,3\% badanych z grupy liczącej 1812 wystąpiła reakcja alergiczna na utlenione formy R-limonenu, a u $2 \%$ na produkty utlenienia S-limonenu [4].

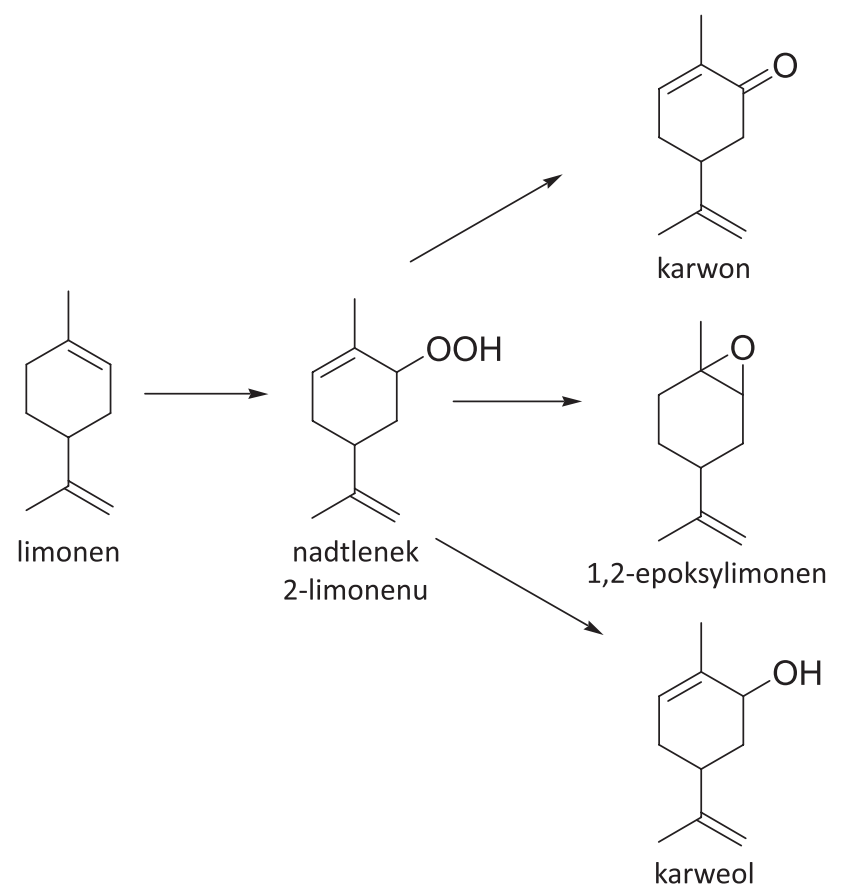

RYCINA 3. Struktury produktów utlenienia limonenu

Mieszanina utlenionych form izomerów limonenu składa się z kilku produktów, spośród których właściwości alergizujące mają: nadtlenki limonenu, 1,2-epoksylimonen, a także karwon. Spośród tych związków największe właściwości alergizujące wykazują nadtlenki [4].

\section{Działanie przeciwbakteryjne i przeciwgrzybicze}

Jak już wcześniej wspomniano, limonen wykazuje działanie bakteriobójcze. Ten cykliczny monoterpen gromadzi się w błonie komórkowej drobnoustrojów i w ten sposób powoduje utratę jej spójności oraz zaburza transport protonów przez błonę, czyli siłę protonomotoryczną. W przeprowadzonych testach aktywności przeciwbakteryjnej na $3 \times 10^{7} \mathrm{CFU}$ Escherichia coli BJ4 na mL (CFU - jednostka tworząca kolonię) działano $200 \mu \mathrm{L}$ R-(+)-limonenu, jednocześnie badano występowanie mutacji polimerazy RNA (rpoS). Badania prowadzono przy pH o wartości 4 lub przy pH o wartości 7 oraz w czasie 10 min, 6 godz. lub 24 godz. Lepsze efekty w inaktywacji limonenem bakterii Escherichia coli BJ4 osiągnięto, stosując środowisko kwaśne. Naukowcy zgłębiając dezaktywujący mechanizm działania R-(+)-limonenu na patogeny, stworzyli proces wykorzystujący podgrzewanie, który pozwolił na inaktywację bakterii Escherichia coli obecnych w sokach owocowych, co pokazuje, że limonen ma potencjał do zastosowania jako substancja konserwująca żywność [5].

W innych badaniach wykazano, że przeciwbakteryjne właściwości izomerów limonenu R i S różnią się znacząco. (S)-(-)-limonen wykazuje małą aktywność przeciwbakteryjną i przeciwgrzybiczą. Izomer ten dał dobre rezultaty, gdy został zastosowany przeciw Microsporum gypseum, wywołującemu grzybice u ludzi. Z kolei R-(+)-limonen wykazuje wysoką aktywność przeciwko szerokiemu spektrum mikroorganizmów. Wrażliwe na działanie R-(+)-limonenu okazały się bakterie odpowiedzialne za powstawanie próchnicy zębów u ludzi (Streptococcus mutans). Izomer ten hamuje namnażanie się pleśni (Aspergillus niger) i innych mikroorganizmów, co sprawia, że R-(+)-limonen może być szczególnie przydatny w hamowaniu namnażania się mikroorganizmów, wywołujących szkody w uprawach roślin czy powodujących psucie się żywności [6].

\section{Limonen jako substancja wspomagająca wchtanianie leków}

Indometacyna - kwas 1-(p-chlorobenzoilo)-5-metoksy-2-metyloindolo-3-octowy - jest pochodną indolu. Jest to związek będący niesteroidowym lekiem przeciwzapalnym, przeciwbólowym i przeciwgorączkowym, hamujący działanie cyklooksygenazy, enzymu odpowiedzialnego za syntezę prostaglandyn oraz autokoid. Substancja ta hamuje również ruchliwość leukocytów obojętnochłonnych (ryc. 4).

Indometacyna jest stosowana w leczeniu chorób reumatoidalnych (zapaleniu stawów i ścięgien). Jej dłuższe doustne przyjmowanie powoduje dolegliwości od strony układu

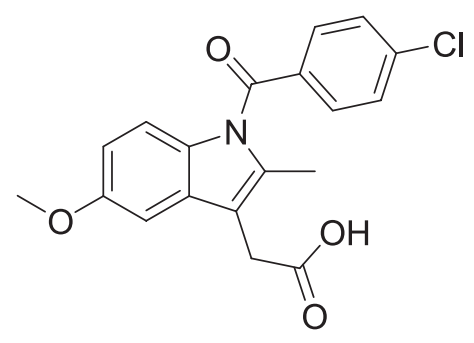

RYCINA 4. Struktura indometacyny 


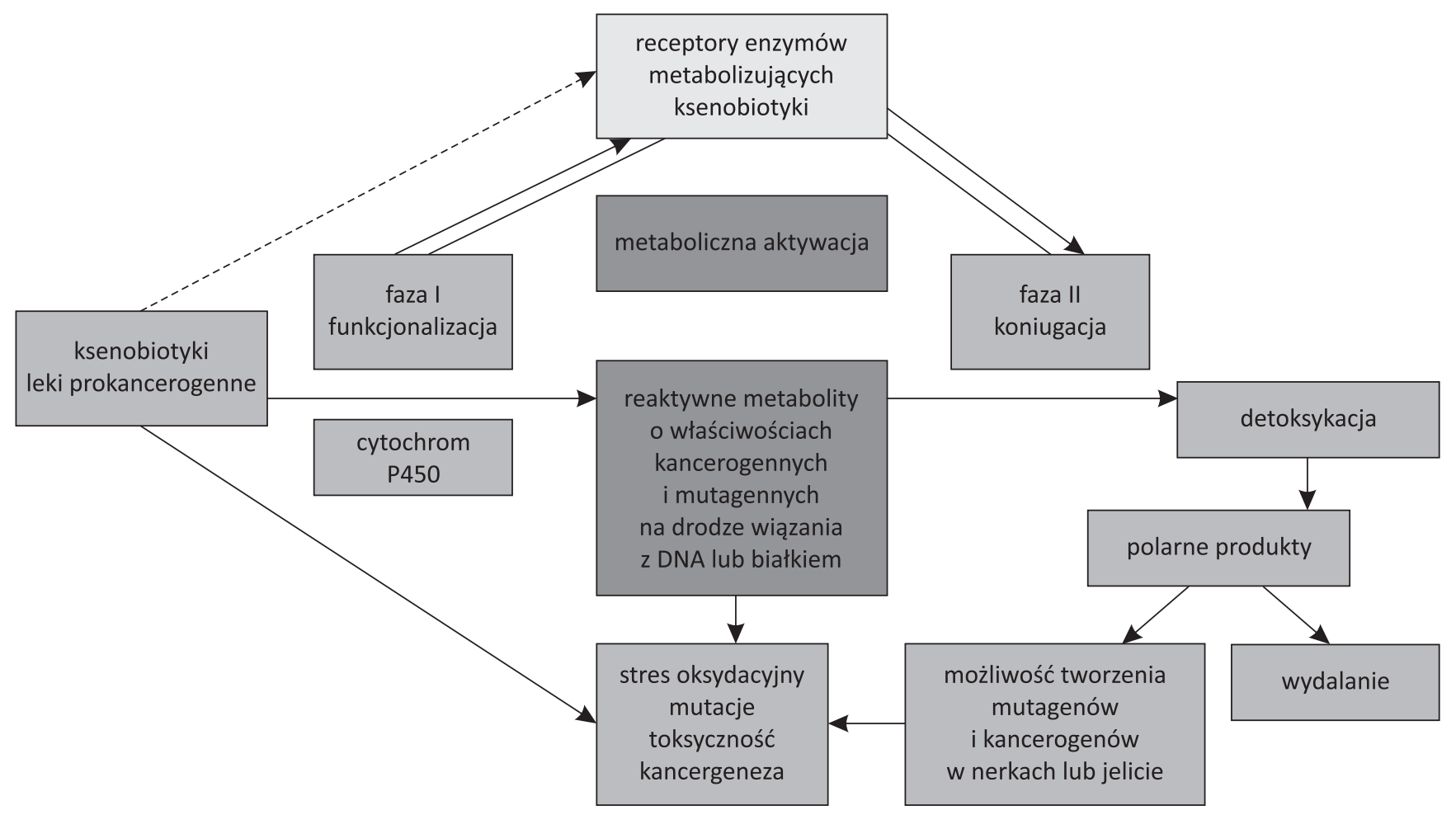

RYCINA 5. Ogólny schemat fazy I i II metabolizmu ksenobiotyków

pokarmowego. Z tego powodu korzystne jest stosowanie leku w formie żelu, podawanego miejscowo. Związkiem, który powoduje znaczną poprawę wchłaniania leku, jest limonen. Podobne efekty dawały inne związki terpenowe, takie jak: $\alpha$-terpinen, jednak gorsze rezultaty osiągnięto podczas zastosowania terpenów zawierających w swojej strukturze grupę hydroksylową lub karboksylową. W badaniu podczas stosowania limonenu nie zaobserwowano nieodwracalnych zmian barierowych właściwości skóry dla transportu leków. Zauważono natomiast, że wraz ze zwiększaniem ilości etanolu w preparacie (hydrożelowej maści) zwiększało się stężenie indometacyny w osoczu. Stąd wniosek, że etanol może zwiększać aktywność limonenu wzmagającego wchłanianie preparatu [7, 8].

\section{Działanie przeciwnowotworowe}

R-limonen indukuje I i II fazę metabolizmu kancerogenów katalizowanych przez enzymy (cytochrom P450) do mniej toksycznych form i zapobiega interakcji kancerogenów z DNA (ryc. 5) [9].

Badania dowodzą, że R-limonen zarówno zapobiega rozwojowi nowotworów, jak i działa terapeutycznie, przy czym nie wykazuje toksyczności. W badaniach na zwierzętach wykazano, że limonen hamuje rozwój raka wątroby, płuc, a także gruczolaka przedżołądka. Ponadto R-limonen hamuje rozwój raka sutka u szczurów, wywołanego przez czynnik rakotwórczy działający pośrednio (dimetylobenzantracen - DMBA) oraz kancerogen działający bezpośrednio (N-metylo-N-nitrozomocznikMNU), który jest środkiem alkilującym oddziałującym z DNA. Hamujące działanie limonenu zostało zaobserwowane zarówno w fazie inicjacji, jak i rozwoju (promocji) raka indukowanego DMBA, natomiast zmiany nowotworowe wywołane MNU były hamowane jedynie w fazie rozwoju kancerogenezy (ryc. 6).

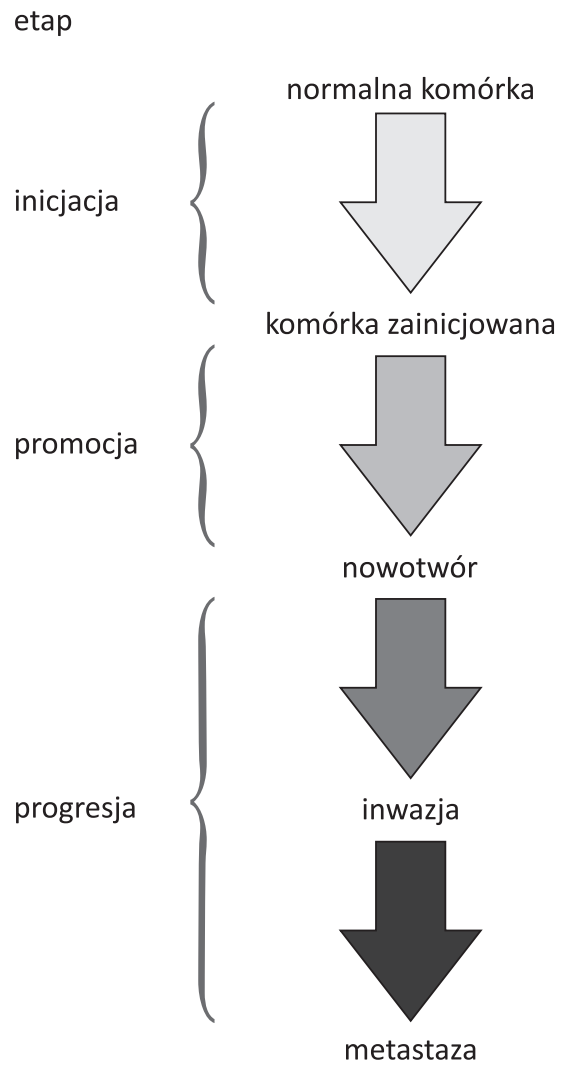

RYCINA 6. Etapy kancerogenezy 


\section{Hamowanie prenylacji białka Ras}

Ras jest protoonkogenem, czyli genem obecnym w prawidłowej komórce, potencjalnie zdolnym do wyzwolenia procesu transformacji nowotworowej. Gen ten jest odpowiedzialny za kodowanie białka, które w odpowiedzi na sygnały zewnątrzkomórkowe uruchamia ścieżki sygnałowe, które umożliwiają komórkom przeżycie i namnażanie się. Odpowiednia regulacja aktywności Ras jest kluczowa dla utrzymania homeostazy komórki i całego organizmu. Mutacje w Ras, które przekształcają je w onkogen, jednocześnie prowadzą do powstania aktywnego białka, które jest obecne w ok. 30\% nowotworów, szczególnie w ich typach charakteryzujących się najwyższą śmiertelnością. Stwierdzono mutację w białku Ras w ok. 50\% przypadków raka okrężnicy i ok. 90\% przypadków raka trzustki. Prenylacja białek to potranskrypcyjna modyfikacja polegająca na przyłączeniu 15-węglowego pirofosforanu farnezylu lub 20-węglowego pirofosforanu geranylogeranylowego. Wiele prenylowanych białek reguluje wzrost i/lub transformację komórek. Upośledzenie prenylacji jednego białka lub większej ilości białek może stanowić o aktywności przeciwnowotworowej limonenu. Białko Ras odgrywa istotną rolę w kancerogenezie. W związku z tym, że ulega ono prenylacji, inhibitory prenylacji tego białka są uznawane za potencjalne leki przeciwnowotworowe. Badania wykazały, że limonen selektywnie hamuje prenylację białka Ras, nie wpływając na prenylację lamin pełniących funkcje strukturalne i regulacyjne podczas mitozy $[10,11,12]$.

Jak już wcześniej wspomniano, R-limonen w organizmie człowieka metabolizuje m.in. do R-kwasu perillylowego, który również został przebadany pod kątem hamowania prenylacji. Badaniu poddano hamowanie prenylacji białek w cytoplazmie komórek mózgu szczura. Chociaż R-limonen i S-limonen są słabymi inhibitorami prenylacji enzymów, okazało się, że ich metabolity - kwas perillylowy i alkohol perillylowy wykazują wysoką aktywność hamującą prenylację białek, w tym białka Ras. Dla metabolitów limonenu wyznaczono średnie stężenie inhibitora, hamujące aktywność biologiczną lub biochemiczną IC $_{50}$, która jest kilkukrotnie niższa niż w przypadku limonenu. Na przykład w przypadku zastosowania limonenu stężenie inhibitora $\mathrm{IC}_{50}$, hamujące prenylację pirofosforanu farnezylu, wynosi powyżej $40 \mathrm{mM}$, podczas gdy dla kwasu R-perillylowego ok. 9 mM. Stężenia IC $_{50}$ obu izomerów limonenu (S i R) hamujące przyłączanie pirofosforanu farnezylu oraz pirofosforanu geranylogeranylowego są jednakowe (powyżej $40 \mathrm{mM}$ ). Inaczej jest w przypadku metabolitów limonenu. Stężenie IC $_{50}$ kwasu R-perillylowego hamujące przyłączanie pirofosforanu farnezylu jest wyższe (ok. $10 \mathrm{mM}$ ) w stosunku do stężenia $\mathrm{IC}_{50}$ hamującego przyłączanie pirofosforanu geranylogeranylowego (ok. 3,5 mM) [13].

W badaniach gryzoni wykazano działanie limonenu w połączeniu z 4-hydroksyandrostendionem na kancerogenny N-nitrozometylomocznik, który wywołuje raka sutka u szczurów. Podawanie szczurom limonenu, który stanowił 10\% ich diety, powodowało całkowitą regresję guzów u wszystkich zwierząt, podczas gdy dawki limonenu stanowiące $5 \%$ pożywienia, powodowały regresję guza jedynie u 50\% badanych zwierząt.
Natomiast zastosowanie limonenu stanowiącego 5\% diety szczurów w połączeniu z 4-hydroksyandrostendionem dało lepsze rezultaty (regresję nowotworu powyżej 83\%) niż w przypadku zastosowaniu tych czynników osobno [14].

\section{Limonen w leczeniu zgagi}

R-limonen ma mniejszą gęstość niż woda, dlatego po spożyciu utrzymuje się na powierzchni soków żołądkowych. Badania wykazały, że limonen łagodzi objawy u osób, u których sporadycznie występuje zgaga, oraz u osób cierpiących na chorobę refluksową przełyku. W przeprowadzonych badaniach wzięło udział 19 dorosłych cierpiących na chroniczną zgagę lub chorobę refluksową przełyku (ryc. 7), którym podawano limonen w celu złagodzenia objawów. Uczestnicy badania mieli przewlekłą zgagę lub objawy choroby refluksowej przełyku, od łagodnych przez umiarkowane do ostrych, przez okres co najmniej 5 lat. Każdy z uczestników badania przed podaniem limonenu został poproszony o ocenę uciążliwości objawów w skali 1-10, gdzie 1 oznaczało brak dolegliwości, a 10 odpowiadało bolesnym objawom występującym na co dzień. Większość badanych oceniła swój stan na 5 lub więcej. Badane osoby po odstawieniu dotychczas stosowanych leków przyjmowały $1000 \mathrm{mg}$ limonenu w formie kapsułki codziennie lub co drugi dzień oraz oceniały swoje samopoczucie wg wcześniej opisanej 10-punktowej skali. W drugim dniu stosowania limonenu $32 \%$ uczestników badania doświadczyło znaczącej poprawy samopoczucia. Oceniali swój stan o 1 lub 2 pkt w skali niżej niż przed zastosowaniem limonenu. W 14. dniu stosowania limonenu u 89\% pacjentów całkowicie ustąpiły objawy $[15,16]$.

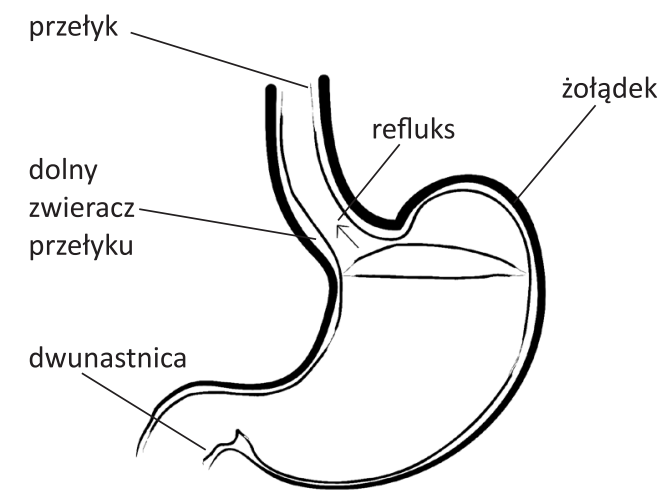

RYCINA 7. Zawracanie treści pokarmowej z żołądka - refluks

Pacjentom podczas eksperymentu po zażyciu limonenu odbijało się. Pomysłodawca leczenia zgagi limonenem, Joe S. Wilkins, sugerował, że pojawianie się lekkiego odbijania po zażyciu limonenu wspomaga doprowadzanie tego składnika olejku eterycznego wprost do przełyku $[15,16]$.

Wyniki badań świadczą o tym, że najlepsze efekty działania R-limonenu osiągnięto po przyjęciu 10 kapsułek. Mechanizm działania tego monoterpenu nie został w pełni wyjaśniony. Badania in vivo sugerują, że limonen blokuje działania kwasu żołądkowego poprzez pokrywanie ścian żołądka, a tym samym chroni błonę śluzową żołądka przed niekorzystnym działaniem nadmiaru kwasów żołądkowych. Limonen pokrywając ściany 
przełyku, chroni go przed działaniem treści żołądkowych powracających z żołądka. Ponadto limonen może powodować szybszy przepływ żywności i soków żołądkowych, co w konsekwencji powoduje, że drażniąca przełyk zawartość żołądka nie zawraca. Dowodem na prawidłowość hipotezy, jakoby R-limonen wspierał fizjologiczną (prawidłową) perystaltykę, są badania na zwierzętach, które wykazały zwiększenie napięcia spoczynkowego w tkankach jelita krętego świnki morskiej i nasieniowodów szczura $[15,16]$.

Dodatkowo, pokrywanie błony śluzowej przełyku i żołądka przez limonen, może chronić je przed infekcjami bakteryjnymi, a jak wiadomo zakażenie bakteriami Helicobacter pylori zwiększa ryzyko zachorowania na raka żołądka $[15,16]$.

\section{Limonen w leczeniu kamicy dróg żółciowych}

Limonen powoduje rozpuszczanie kamieni żółciowych, dając podobny efekt do rozpuszczalników organicznych, takie jak eter czy chloroform. Rozpuszczanie cholesterolu przez R-limonen przebiega podobnie jak rozpuszczanie substancji o zbliżonej polarności przez wymienione rozpuszczalniki organiczne. Kamienie żółciowe obecne w drogach żółciowych są całkowicie zanurzone w żółci. R-limonen nie styka się z powierzchnią kamieni, ponieważ nie miesza się z żółcią, dlatego do limonenu dodaje się niewielką ilość środków powierzchniowo czynnych, które umożliwiają mieszanie się obu cieczy (ryc. 8).

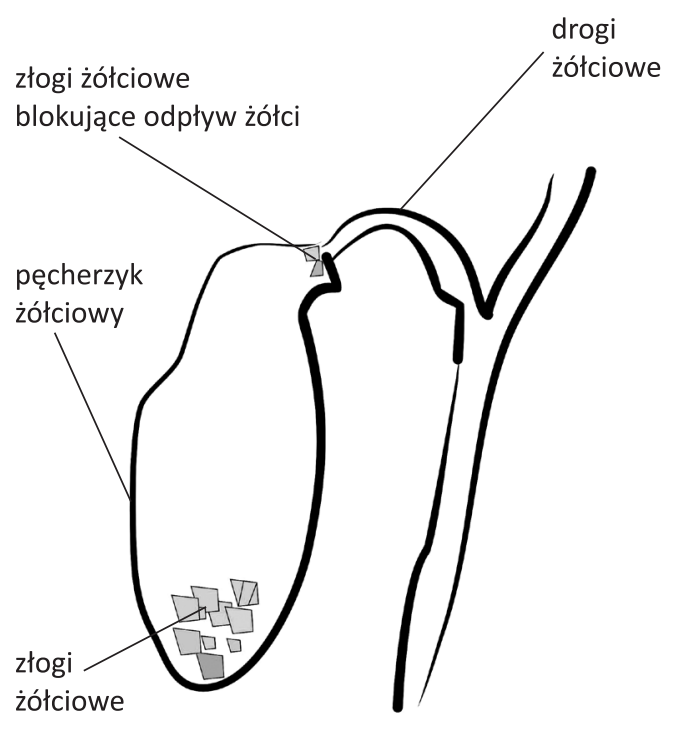

RYCINA 8. Złogi żółciowe w pęcherzyku żółciowym

Z wcześniejszych badań wynika, że poprzez energiczne mieszanie układ składający się z wody i R-limonenu rozpuszcza cholesterol, gdy zawartość limonenu w tym układzie wynosi 50-60\% całkowitej objętości. Układ woda-limonen tworzy emulsję, w której R-limonen stanowi fazę ciągłą, w której zdyspergowane są krople wody.

Badania pokazały, że R-limonen skutecznie rozpuszczał kamienie żółciowe (złogi), które zawierały w swoim składzie więcej niż 70\% cholesterolu. W 14 przeprowadzonych doświadczeniach 3-25 dawek mieszaniny zawierającej limonen powodowało rozpuszczenie kamieni żółciowych, które nie zostały usunięte z dróg żółciowych pacjentów w czasie zabiegu operacyjnego. Pozytywny efekt działania jest szczególnie widoczny w doświadczeniu, w którym preparat zawierający limonen spowodował rozpuszczenie 5 kamieni w 23 dawkach po 20 mL. Cztery kamienie znajdujące się w przewodzie żółciowym wspólnym zostały rozpuszczone w pierwszej kolejności, a następnie rozpuszczony został kamień obecny w brodawce większej dwunastnicy, stanowiącej połączenie przewodu żółciowego wspólnego i przewodu trzustkowego. Wykonane badania histopatologiczne i biopsja wątroby nie wykazały znaczących zmian po podaniu preparatu zawierającego limonen, co jest wystarczającym dowodem na to, że infuzja R-limonenu jest bezpiecznym sposobem usuwania kamieni żółciowych. Stan niektórych osób, u których zastosowano infuzję preparatu z limonenem, był obserwowany przez 2 lata. Pacjenci byli poddawani badaniom takim jak: duodendografia i cholangiografia, które stosowano w połączeniu z badaniami laboratoryjnymi. Badania te również nie wykazały nieprawidłowości. Pozytywne efekty dają nadzieje na stosowanie preparatów składających się głównie z limonenu, które mogą być stosowane w leczeniu kamicy dróg żółciowych bez konieczności interwencji chirurgicznej [17].

\section{PODSUMOWANIE I WNIOSKI}

W przedstawionych badaniach limonen wykazuje właściwości, które pozwalają na wykorzystanie go bezpośrednio jako leku, np. powodującego rozpuszczanie kamieni żółciowych. Związek ten jest również wykorzystywany pośrednio w leczeniu, umożliwiając wchłanianie np. indometacyny (ryc. 9).

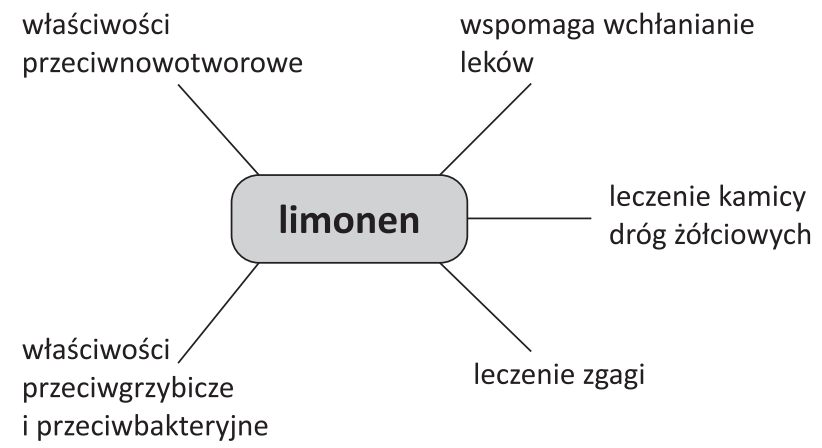

RYCINA 9. Przykłady leczniczych właściwości limonenu, umożliwiających jego zastosowanie $w$ medycynie

Zaletą stosowania limonenu jest jego łatwe pozyskiwanie z odpadów (skórek pomarańczowych). Ponadto jest to związek naturalny, spożywany wraz z pokarmem w znacznych ilościach, co świadczy o tym, że jest bezpieczny dla organizmu człowieka (potwierdzają to również badania naukowe). Chociaż sam limonen nie wykazuje właściwości alergizujących, produkty jego utlenienia powodują alergię, dlatego stosowanie limonenu powinno być przemyślane, aby nie dopuszczać do kontaktu z alergenami. Pomimo tej niedogodności, warto rozwijać badania nad medycznymi zastosowaniami limonenu, 
gdyż jak wykazały dotychczasowe badania, ma on olbrzymi potencjał w leczeniu chorób, z którymi boryka się znacząca część społeczeństwa. W omówionych w artykule badaniach limonen wykazuje przydatne właściwości, takie jak: zwiększenie perystaltyki jelit, co może być wykorzystane np. w leczeniu zaparć. Ponadto wykazuje on bakteriobójcze właściwości przeciw bakteriom wywołującym próchnicę, co z kolei może być przydatne w profilaktyce stomatologicznej. Związek ten, pokrywając błonę śluzową żołądka, może zapobiegać nowotworom dzięki ochronie przed infekcjami bakteryjnymi, takimi jak Helicobacter pylori. Obecnie zwraca się w medycynie uwagę na to, aby w leczeniu szukać rozwiązań o minimalnym ryzyku dla pacjentów, a zastosowanie limonenu w leczeniu kamicy może uchronić pacjenta przed inwencją chirurgiczną.

\section{PIŚMIENNICTWO}

1. Espina L, Gelaw TK, de Lamo-Castellví S, Pagán R, García-Gonzalo D. Mechanism of bacterial inactivation by (+)-limonene and its potential use in food preservation combined processes. PLoS One 2013;8(2):e56769. doi: 10.1371/journal.pone.0056769.

2. Choi HS. Character impact odorants of citrus hallabong. J Agric Food Chem 2003;51(9):2687-92. doi: 10.1021/jf021069o.

3. Khan AA, Mahmood T, Siddiqui HH, Akhtar J. Phytochemical and pharmacological properties on Citrus limetta (Mosambi). J Chem Pharm Res 2016;8(3):555-63.

4. Matura M, Sköld M, Börje A, Andersen KE, Bruze M, Frosch P, et al. Not only oxidized R-(+)- but also S-(-)-limonene is a common cause of contact allergy indermatitis patients in Europe. Contact Dermatitis 2006;55(5):274-9. doi: 10.1111/j.1600-0536.2006.00939.x.
5. Espina L, Gelaw TK, de Lamo-Castellvı S, Pagan R., Garcı-Gonzalo D. Mechanism of bacterial inactivation by (+)-limonene and its potential use in food preservation combined processes. PLoS One 2013;8(2):e56769. doi: 10.1371/journal.pone.0056769.

6. Aggarwal KK, Khanuja SPS, Ahmad A, Kumar TRS, Gupta VK, Kumar S. Antimicrobial activity profiles of the two enantiomers oflimonene and carvone isolated from the oils of Menthaspicata and Anethum sowa. Flavour Fragr J 2001;17(1):59-63. doi: 10.1002/ffj.1040.

7. Okabe H, Takayama K, Ogura A, Nagai T. Effect of limonene and related compounds on the percutaneous absorption of indomethacin. Drug Des Deliv 1989;4(4):313-21.

8. Turek M, Łodyg-Chruścińska E. Zastosowanie w medycynie pochodnych indolu i jego kompleksów z biometalami. Food Chem Biotechnol 2008;72:73-88.

9. Karasiewicz M. Analiza wpływu surowców roślinnych na poziom ekspresji wysoce konserwatywnych izoenzymów cytochromu P-450 CYP1A2 i CYP2E1 u szczurów [dissertation]. Poznań: Uniwersytet Medyczny w Poznaniu; 2012.

10. Mosieniak G, Strzeszewska A. Rola starzenia komórkowego w kancerogenezie i terapii przeciwnowotworowej. Postępy Biochem 2014;60(2):194-206.

11. Bartczak M, Sałagacka A, Mirowski M, Balcerczak E. Status genu K-RAS jako czynnik prognostyczny i predykcyjny w raku jelita grubego. J Oncol 2010;60(2):147-56.

12. Świeżewska E. Prenylacja białek. Postępy Biochem 1995;41(1):51-8.

13. Hardcastle IR, Rowlands MG, Barber AM, Grimshaw RM, Mohan MK, Nutley BP, et al. Inhibition of protein prenylation by metabolites of limonene. Biochem Pharmacol 1999;57(7):801-9.

14. Chander SK, Lansdown AG, Lugmani YA, Gomm JJ, Coope RC, Gould N, et al. Effectiveness of combined limonene and 4-hydroxyandrostenedione in the treatment of NMU-induced rat mammary tumours. Br J Cancer 1994;69(5):879-82.

15. Wilkins J. Method for treating gastrointestinal disorder. US patent 642045 . 2002.

16. Martin R. Natural relief from heartburn! LE Magazine, September 2006.

17. Igimi $H$, Hisatsugu $T$, Nishimura M. The use of d-limonene preparation as a dissolving agent of gallstones. Am J Dig Div 1976;21(11):926-39. 